\title{
Role of Corporate Governance in Banking Sector: Evidence from All Over the World
}

\author{
Anastasia Stepanova ${ }^{20}$, Olga Ivantsova ${ }^{21}$
}

This paper is focused on the recent research in the area of performance effect of corporate governance in banking sector. We review the results of studies devoted to two key nonfinancial characteristics of a commercial bank influencing its performance. In the first part of the paper we analyze the evidence on board of directors structure impact on bank performance. We focus on the performance effect of board size, independent directors and gender diversity of the board. In the second part we discuss the issue of bank ownership structure. In this paper we pay special attention to the difference between performance drivers in developed and emerging markets as well as to the performance drivers changes in times of financial crisis.

JEL: G32, G34.

Keywords: corporate governance, bank performance, commercial banks, independent directors, ownership structure, emerging markets

\section{Introduction}

The financial crisis of 2007-2009 showed how little we know about the governance of banks and how crucial the sustainability of banking sector is. Corporate governance of banks has special relevance due to the specifics of the banking sector and its very special function in the economy. Hence, we need better understanding of corporate governance as a driver for bank performance.

The Basel Committee on Banking Supervision has called attention to the need to study and improve the corporate governance of financial institutions even before the financial crisis by stating that good corporate governance is necessary to guarantee a sound financial system. Improving corporate board structure, in respect of size and composition, has been one of the main issues in corporate governance initiatives undertaken by international authorities in last decade (EU Commission Communication, 2003; Basel Committee, 2006). Additionally, corporate governance is regulated by national institutions and the framework of such regulation is forming and changing over time: UK, Germany and Norway, ones of the most developed European countries, updated their codes of corporate governance in 2012.

On the other hand ownership structure is not regulated and only a shareholder structure is a subject of mandatory disclosure for some companies. In the last two decades many mergers and acquisitions in the banking sector took place all over the world and changed banks' ownership type from government to private or from domestic to foreign and increased the average level of ownership concentration. These changes raised important research questions, for example, what type of ownership and level of concentration are better for bank performance.

The main purpose of this paper is to review a number of existing research papers on the impact of corporate governance mechanisms over performance of commercial banks. In Section 2 we discuss the empirical evidence on the board of directors' influence on bank performance. Section 3 reviews the performance effect of ownership concentration and types of owners. Section 4 concludes.

\footnotetext{
${ }^{20}$ Corporate Finance Department, Corporate Finance Center, National Research University Higher School of Economics, Moscow, RUSSIA: Assistant Professor, Researcher, anastasianstepanova@gmail.com

${ }^{21}$ Corporate Finance Department, Corporate Finance Center, National Research University Higher School of Economics, Moscow, RUSSIA, Junior Researcher, olgamivantsova@gmail.com
} 


\section{Board of Directors and Bank Performance \\ 2.1 Board Size and its impact on Bank Performance}

From a theoretical point of view, larger boards of directors gather more human capital, knowledge and experience and it helps the board provide the management with better monitoring and advising. On the other hand, if there are too many members on the board it creates additional problems with coordination and communications between directors in comparison to smaller boards. Within larger boards more compromises should be reached to make a decision, which makes this process less flexible and more time consuming. In general, the effect of board size on bank value is a trade-off between advantages (human capital) and disadvantages (coordination problems).

Therefore, such a trade-off should create a nonlinear relation between board size and bank performance, however very little proof of this relation can be found in the existing literature. Andres and Vallelado report a reverse nonlinear relationship between number of directors in the board and bank performance measured as return on assets and Tobin's Q for Western European countries and USA (Andres, Vallelado, 2008). This type of a relationship implies that a board size optimal for performance can be determined. Grove et al. find a concave relationship between financial performance and board size for US banks (Grove et al., 2011).

However, the majority of authors find this relation between board size and performance to be negative showing that the disadvantages of large boards are generally stronger than the advantages. Sakawa and Watanabel, analyzing the Japanese banking sector, find that banks with larger boards "underperform their peers in terms of Tobin's Q" (Sakawa, Watanabel, 2011). Staikouras et al. show negative correlation between board size and performance as ROA, ROE and Tobin's Q for European banks (Staikouras et al., 2007). For non-developed countries the same negative relationship is reported by Adusei for banks' return on equity in Ghana and by Pathan et al. for return on assets and equity and Sharp ratio in the Thai banking sector (Adusei, 2011; Pathan et al., 2007).

Nevertheless, some authors show the positive relation arguing that the banking sector differs from the other sectors very much and additional knowledge and experience provided by larger boards contributes to better bank performance. For the US banks Adams and Mehran identify the significant positive correlation between board size and Tobin's Q during the period from 1959 till 1995 and Aebi et al. demonstrate the same for bank returns during a very special period - the financial crisis of 2007-2008 (Adams, Mehran, 2008; Aebi et al., 2012). Belkhir for the sample of 174 bank and savings and loans holding companies reports that there is a positive relationship between the size of the board of directors and performance measured by Tobin's $Q$ and return on assets (Belkhir, 2009). For non-developed countries only Kyereboah-Coleman and Biekpe show a positive relation between ROA and board size for banks in Ghana (Kyereboah-Coleman, Biekpe, 2006).

However, such authors like Adams and Mehran and Grove et al. for US banks, Bino and Tomar for Jordanian public banks, Love and Rachinsky for Russia and Ukraine find that board size has no effect on bank's return on assets (Adams, Mehran, 2008; Grove et al., 2009; Bino, Tomar, 2012; Love, Rachinsky, 2008). Tandelilin et al. demonstrate that the relationship between board size and bank performance in insignificant for Indonesia and Zulkafli and Samad show it for Malaysia, Thailand, Philippines, Indonesia, Korea, Hong Kong, Taiwan and India (Tandelilin et al., 2007; Zulkafli, Samad, 2007).

\subsection{Independent directors: do they contribute to value or not?}

The second most popular research question is an effect of board independence. However the previous literature does not provide us with a conclusion regarding the effect of outside directors in the board. On the one hand, independent directors have fewer conflicts of interest when monitoring managers; they are less dependent on the CEO's opinion and they have reputational incentive to perform their functions better. If the poor performance of the board results in poor performance of the firm it can damage a reputation of an independent director, which is important as many of them 
serve in more than one board of directors. On the other hand, an excessive proportion of nonexecutive directors could damage the advisory role of boards since they may not have some information about the company, which can be easily accessible for insiders. So there is also a tradeoff between the advantages and disadvantages of non-executive directors. Moreover, some authors point out that the effectiveness of outside directors depends on the cost of acquiring information about the firm: when the cost of acquiring information is low, outsiders in board of directors increase performance (Duchin et al., 2010).

Andres and Vallelado support the hypothesis about the tradeoff in the situation with independent directors and show the reverse nonlinear relation between them and US bank performance, which also implies the existence of an optimal percentage of outsiders in the board (Andres, Vallelado, 2008).

Both the codes of corporate governance in many countries and the Basel Committee recommend having a substantial proportion of outsiders in the board taking into account the advantages of their independence. Grove et al. provide empirical evidence regarding positive effect of outsiders for return on assets and Tobin's Q for US banks, Busta does it for Tobin's Q and returns on invested capital for banks in continental Europe and Pathan et al. prove it for returns of banks in Thailand, though Busta reports an opposite relationship for banks in the United Kingdom (Grove et al., 2009; Busta, 2008; Pathan et al., 2007). Rowe et al. demonstrate that lower percentage of insiders on the board is associated with better bank performance in China (Rowe et al., 2011).

Still a few authors show a negative effect of outside directors, for example KyereboahColeman and Biekpe for Ghanaian banks and Bino and Tomar, who report that the majority of affiliated directors on the board is correlated with higher performance (Kyereboah-Coleman, Biekpe, 2006; Bino, Tomar, 2012).

Pi and Timme, Adams and Mehran and Aebi et al. find no significant relation between the degree of board independence and performance of US banks (Pi, Timme, 1993; Adams, Mehran, 2008; Aebi et al., 2011). For the European banks Staikouras et al. report the same for returns and Tobin's Q and Busta shows it for return on assets (Staikouras et al., 2007; Busta, 2008). Sakawa and Watanabel find no significant relation between the proportion of outside directors on the board and Tobin's Q for banks in Japan (Sakawa, Watanabel, 2011). For emerging countries this finding is common for Tandelilin et al. for Indonesia, Choi and Hasan for Korea and Love and Rachinsky for Russia and Ukraine (Tandelilin et al., 2007; Choi, Hasan, 2005; Love, Rachinsky, 2008).

\subsection{Gender diversity efficiency}

The next characteristic of board of directors that receives more and more attention in the research literature and regulatory discussions in the last decade is gender diversity. The opinion that gender diversity can be beneficial to business is widely accepted, however the rate at which women are being integrated into senior positions remains extremely slow. Amongst the largest public companies across Europe, men account for $89 \%$ of board members and women just 11\% (European Commission, 2010). Norway stands out as it is the only country that is relatively close to gender equality with $42 \%$ women on the boards of the largest listed companies. This is a direct result of the regulation implemented in 2006.

Motivation that is behind such regulation is of a great interest. Some studies provide empirical evidence that companies with the highest share of women in executive committees outperform companies with no women, for example, in terms of return on equity by 41 percent (McKinsey\&Company, 2010). Farrel and Hersh also find that companies with more women in their boards show better performance (Farrel, Hersh, 2005). Though this does not mean strict causality, it does provide a basis for discussions about benefits of greater gender diversity in board rooms.

One of the explanations of the positive effect of diversity among board members is that it increases creativity and innovation by adding complementary knowledge, skills and experience. More diverse boards evaluate more alternatives compared to homogenous boards during the decision making process and that leads to better corporate performance. Some researches argue that a gender-balanced board is more likely to pay attention to managing and controlling risk (European 
Commission, 2012). Adams and Ferreira show for the sample of US firms that more diverse boards allocate more human resources to monitoring, however on average the impact of gender diversity on firm performance is negative (Adams, Ferreira, 2009).

There are other characteristics of the board of directors that receive much less attention in the existing literature. For example, CEO duality which means the positions of the CEO and Chairman of the Board of Directors are taken by the same person. Pi and Timme find that banks with a dual CEO underperform in terms of ROA (Pi, Timme, 1993). However Simpson and Gleason report that CEO duality is related to lower probability of financial distress. Their argument is that such a CEO will make less risky decisions to keep his position. Grove et al. demonstrate for US banks that CEO duality is negatively associated with financial performance (Grove et al., 2011).

\section{Ownership structure and Bank Performance}

An ownership structure can be defined along two main dimensions. First is the degree of ownership concentration. Second is the type of the owners: state, foreign, institutional, management, etc.

\subsection{Performance Effect of Ownership concentration}

A high ownership concentration may have a positive effect on a firm's values as large shareholders have more incentives to monitor the bank's management. On the other side, large shareholders may have too much influence on the board and the management and if they have other goals besides share value maximization (like government), it may not be effective for the firm itself and also for the minority shareholders. The quality of their monitoring may be also not very high if they do not have relevant knowledge and experience.

Grove et al. show that a presence of a majority shareholder is positively associated with performance of US banks in terms of Tobin's Q and ROA (Grove et al., 2009). Chang et al., studying effects of diversification and reporting its negative impact of bank's performance, show that "banks with a dominant owner suffer less from diversification than those without a dominant owner" (Chang et al., 2009). Rowe et al. for Chinese banks and Riewsathirathorn et al. for EastAsian banks demonstrate that lower block ownership is associated with better performance (Rowe et al., 2011; Riewsathirathorn et al., 2011).

Pi and Timme for US banks and Ianotta et al. for large European banks show that ownership concentration is unrelated to bank's profitability (Pi, Timme, 1993; Ianotta et al., 2007).

Some authors find more complicated nonlinear relationship between ownership concentration and bank's performance. For example, Antoniadis et al. find a statistically significant quadratic relationship between ownership and performance for Greek banks (Antoniadis et al., 2010). Furthermore, Magalhaes et al. for 795 banks from 47 countries report a cubic relationship between ownership concentration and bank performance (Magalhaes et al., 2010).

Busta confirms that the effect may differ for the different institutional settings (Busta, 2008). The author finds that the effect of an increase in ownership concentration on Tobin's Q may be beneficial in France and Scandinavian countries but may be punished by investors in the Germany and UK.

\subsection{Type of owner: does it matter for bank performance?}

Among other characteristics of bank ownership that are being studied are types of shareholders: institutions, management, foreigners and government. Many authors show a negative influence of state ownership (e.g. see Berger et al., 2005; Farazi et al., 2011 for Middle East and North Africa; Berger et al., 2009 and Lin \& Zhang, 2009 for China; Micco et al., 2007 for developing countries). At the same time in times of global financial crisis we should take into account the potential positive influence of state as a bank owner on bank financial stability and performance. Although we failed to find significant evidence for this relationship during recent financial global crisis, we could support this statement with strong evidence from Asian crisis of 
early 2000s (Cornett et al., 2010).

Stable governance traditions, deeper experience, higher level of discipline, better access to global capital market generally allow banks with foreign owners outperforming domestically-owned banks. A number of empirical studies find a positive performance effect of foreign ownership in emerging markets (e.g. Bonin et al., 2005; Kim, Rasiah, 2010). But results regarding foreign ownership change from country to country. For example, Berger et al. show that in China foreign banks are most efficient, but Lensink et al. report for the worldwide sample that increase in foreign ownership negatively affects bank performance (Berger et al., 2009; Lensink et al., 2007).

\section{Conclusion}

The financial crisis demonstrated the great importance of commercial banks in the economic system, which strengthens the need to study the corporate governance of banks. We analyzed the existing empirical evidence regarding the relationship between corporate governance mechanisms and performance and we observe that there is no common opinion about such relationship.

The researchers obtain the mixed results on the impact of board of directors characteristics its size and independence - over bank performance. Despite the arguments about positive effect of additional human capital provided by larger boards, the most widespread opinion is that the relationship between bank performance and board size is negative. This view is supported by the majority of the papers and shows that the coordination problems in larger boards outweigh its advantages of bigger collection of knowledge. The similar trade-off may be seen for the board independence. Here we observe that if independent directors have a significant effect on bank performance than it is most likely positive due to outside knowledge and experience they bring to the board.

The research of the performance effect of gender diversity is becoming popular among researchers only in the past few years. Most existing empirical evidence shows that female directors provide banks with a better monitoring which leads to a positive relationship between the percentage of women in the board of directors and bank performance.

The results of previous research regarding the ownership concentration effect vary significantly. Nevertheless, some authors agree that having high ownership concentration is not effective for banks and therefore the its relationship with bank performance is negative. The findings about the impact of state ownership are more homogenous and they state that the government as a shareholder may have other goals besides the increasing value of the company which may hurt the bank performance.

The diversity of obtained evidence might be explained by countries' peculiarities, which means that there are some important dissimilarities in how corporate governance influences bank performance in various countries and during different stages of economic cycle. Therefore, when corporate governance principles are being established there has to be taken an individual approach to every country.

\section{References}

1. Adams, R.B., Ferreira, D. (2009), Women in the Boardroom and their impact on governance and performance, Journal of Financial Economics, 94 (2009), 291-309.

2. Adams, R.B., Mehran, H. (2008), Corporate performance, board structure, and their determinants in the banking industry, Federal Reserve Bank of New York Staff Reports, no. 330 .

3. Adusei, M. (2011), Board structure and bank performance in Ghana, Journal of Money, Investment and Banking 19.

4. Aebi, V., Sabato, G., Schmid, M. (2012), Risk management, corporate governance, and bank performance in the financial crisis, Journal of Banking \& Finance, 36 (2012), 3213-3226.

5. Andres, P. de, Vallelado, E. (2008), Corporate governance in banking: The role of the board 
of directors, Journal of Banking and Finance, 32 (2008), 2570-2580.

6. Antoniadis, I., Lazarides, T., Sarrianides, N. (2010), Ownership and performance in the Greek banking sector, International Conference on Applied Economics - ICOAE 2010, Working Paper.

7. Basel Committee on Banking Supervision (2006), Enhancing Corporate Governance for Banking Organizations.

8. Belkhir, M. (2009), Board of directors' size and performance in the banking industry, International Journal of Managerial Finance, Vol. 5, No. 1.

9. Berger, A. N., Clarke, G.R.G., Cull, R., Klapper, L., Udell, G. F. (2005), Corporate governance and bank performance: A joint analysis of the static, selection, and dynamic effects of domestic, foreign, and state ownership, Journal of Banking and Finance, 29 (2005), 2179-2221.

10. Berger, A.N., Hasan, I., Zhou, M. (2009), Bank ownership and efficiency in China: What will happen in the world's largest nation?, Journal of Banking \& Finance, 33 (2009), 113130.

11. Bino, A., Tomar, S. (2012), Corporate governance and bank performance: evidence from Jordanian banking industry, Journal of Business Administration, forthcoming.

12. Bonin, J. P., Hasan, I., Wachtel, P. (2005), Bank performance, efficiency and ownership in transition countries, Journal of Banking and Finance, 29 (2005), 31-53.

13. Busta, I. (2008), Corporate governance in banking: a European study, Copenhagen Business School, The PhD School in Economics and Business Administration, PhD Series 15.2008.

14. Chang, Y., Tsai, H., Lai, K. (2009), Ownership structure, supervisory regulation and the diversification effects on bank performance, Journal of Financial Studies, Vol. 17, No 4.

15. Choi, S., Hasan, I., (2005), Ownership, governance, and bank performance: Korean experience, Financial Markets, Institutions \& Instruments, Vol. 14, No. 4.

16. Cornett, M., Guo, L., Khaksari, S., Tehranian, H. (2010), The Impact of State Ownership on Performance Differences in Privately-Owned versus State-Owned Banks: An International Comparison, Journal Of Financial Intermediation, 19 (2010), 74-94.

17. Duchin, R., Matsusaka, J.G., Ozbas, O. (2010), When Are Outside Directors Effective?, Journal of Financial Economics, 96 (2010), 195-214.

18. European Commission Recommendation, 2005/162/EC.

19. European Commission, 2010, More women in senior positions - Key to economic stability and growth, Directorate-General for Employment, Social Affairs and Equal Opportunities.

20. European Commission, 2012, Women in economic decision-making in the EU: Progress report. A Europe 2020 initiative.

21. Farazi, S., Feyen, E., Rocha, R. (2011), Bank ownership and performance in the Middle East and North Africa region, The World Bank, Policy Research Working Paper 5620.

22. Farrel, K.A., Hersh, P.L. (2005), Additions to corporate boards: the effect of gender, Journal of Corporate Finance, 11 (2005), 85- 106.

23. Grove, H., Patelli, L., Victoravich, L.M., Xu, P. (2009), Corporate governance and performance: evidence from U.S. Commercial Banks, Working paper.

24. Grove, H., Patelli, L., Victoravich, L.M., Xu, P. (2011), Corporate Governance and Performance in the Wake of the Financial Crisis: Evidence from US Commercial Banks, Corporate Governance: An International Review, Vol. 19, 5, 418-436.

25. Hermalin, B.E., Weisbach, M.S. (2003), Board of directors as an endogenously determined institution: A survey of the economic literature, FRBNY Economic Policy Review, 7-26.

26. Iannotta, G., Nocera, G., Sironi, A. (2007), Ownership structure, risk and performance in the European banking industry, Journal of Banking \& Finance, 31 (2007), 2127-2149.

27. Kim, P.K., Rasiah, D. (2010), Relationship between corporate governance and bank performance in Malaysia during the pre and post Asian financial crisis, European Journal of Economics, Finance and Administrative Sciences, 21 (2010), 39-63.

28. Kyereboah-Coleman, A., Biekpe, N. (2006), Do boards and CEOs matter for bank 
performance? A comparative analysis of banks in Ghana, Corporate Ownership and Control, Vol. 4, Issue 1.

29. Laeven, L., Levine, R. (2009), Bank governance, regulation and risk-taking, Journal of Financial Economics, 93 (2009), 259-275.

30. Lensink, R., Naaborg, I. (2007), Does foreign ownership foster bank performance?, Applied Financial Economics, 17 (2007), 881-885.

31. Lin, X., Zhang, Y. (2009). Bank ownership reform and bank performance in China, Journal of Banking \& Finance, 33(1), 20-29.

32. Love, I., Rachinsky, A. (2007), Corporate Governance, ownership and bank performance in emerging markets: Evidence from Russia and Ukraine, Working paper.

33. Magalhaes, R., Urtiaga, M.G., Tribo, J.A. (2010), Banks' ownership structure, risk and performance, Working Paper.

34. McKinsey\&Company, 2010, Women Matter 2010, Women at the top of corporations: Making it happen.

35. Mehran, H., Morrison, A., Shapiro, J. (2011), Corporate Governance and Banks: What Have We Learned from the Financial, Federal Reserve Bank of New York Staff Reports, no. 502.

36. Micco, A., Panizza, U., Yanez, M. (2007), Bank ownership and performance. Does politics matter?, Journal of Banking \& Finance, 31 (2007), 219-241.

37. Minton, B.A., Taillard, J.P.A., Williamson, R. (2010), Do independence and financial expertise of the board matter for risk taking and performance?, Charles A. Dice Center Working Paper No. 2010-14.

38. Pathan, S., Skully, M., Wickramanayake, J. (2007), Board size, independence and performance: an analysis of Thai banks, Asia-Pacific Finan Markets, 14 (2007), 211-227.

39. Pi, L., Timme, S.G. (1993), Corporate control and bank efficiency, Journal of Banking and Finance, 17 (1993), 515-530.

40. Riewsathirathorn, P., Jumroenvong, S., Jiraporn, P. (2011), The impact of ownership concentration on bank performance and risk-taking: evidence from East Asia, The Journal of Emerging Markets, forthcoming.

41. Rowe, W., Shi, W., Wang, C. (2011), Board governance and performance of Chinese banks, Banks and Bank Systems, No. 1, 2011.

42. Sakawa H., Watanabel, N. (2011), Corporate board structures and performance in the banking industry: evidence from Japan, Working Paper.

43. Simpson, W.G., Gleason, A.E. (1999), Board structure, ownership, and financial distress in banking firms, International Review of Economics and Finance, 8 (1999), 281-292.

44. Staikouras, P.K., Staikouras, C.K., Agoraki, M.E. (2007), The effect of board size and composition on European bank performance, European Journal of Law and Economics, 23 (2007), 1-27.

45. Tandelilin, E., Kaaro, H., Mahadwartha, P.A. (2007), Corporate governance, risk management and bank performance: Does type of ownership matter?, EADN individual research grant project No. 34.

46.Zulkafli, A.H., Samad, F.A. (2007), Corporate governance and performance of banking firms: evidence from Asian emerging markets, Advances in Financial Economics, 12 (2007), 49-74. 